\title{
ICT Skills: An Essential Graduate Skill in Today's Global Economy?
}

\author{
Iwona Miliszewska \\ Victoria University, Melbourne, Australia
}

Iwona.Miliszewska@vu.edu.edu

\begin{abstract}
This paper reflects on the skills required by university graduates to participate successfully in today's global economy. The development of these skills in students throughout Australian universities has been guided by Core Graduate Attributes (CGA) policies. While information literacy skills have been recognised in most policies, more advanced information technology and communication (ICT) skills and digital literacy have been largely overlooked. Yet, digital technology is all-encompassing with applications that permeate every aspect of the economy. Thus, the skills that graduates require increasingly revolve around knowledge creation and information sharing, insight and analysis, and collaboration and advanced communications skills. The paper discusses the growing need for the development of advanced ICT skills in university graduates; it shows the disparity between CGA policies, current university practice, and the expectations of the world at large; and, it proposes explicit incorporation of these skills to university curriculum, including suggestions for effective implementation.
\end{abstract}

Keywords: ICT skills, graduate attributes, digital technology, communication skills

\section{Introduction}

There is a growing acceptance among academics, education policy-makers, and employer groups that the development of graduate skills is part of the role of higher education. Employers are seeking graduates with a range of knowledge, skills, abilities, and personal attributes in addition to degree status (B-HERT, 2002). What kind of skills, abilities, and attributes will define a successful graduate in today's global economy? Self-reliance skills appears to be the all-

encompassing answer to this question; it includes awareness of the changing world of work, taking responsibility for own career and personal development, and managing a good relationship with work and with learning throughout all stages of life. The development of self-reliance skills in students has always been a part of the educational process, albeit often in an implicit and informal way. This changed at the beginning of this century following the publication of the Niel-

Material published as part of this publication, either on-line or in print, is copyrighted by the Informing Science Institute. Permission to make digital or paper copy of part or all of these works for personal or classroom use is granted without fee provided that the copies are not made or distributed for profit or commercial advantage AND that copies 1) bear this notice in full and 2) give the full citation on the first page. It is permissible to abstract these works so long as credit is given. To copy in all other cases or to republish or to post on a server or to redistribute to lists requires specific permission and payment of a fee. Contact Publisher@InformingScience.org to request redistribution permission. sen report (ACNielsen, 2000).

Since the publication of the Nielsen report (ACNielsen, 2000), the majority of universities in Australia proceeded with the development of policy addressing the desired attributes of their graduates. However, there appear to be differences between the findings revealed in the Nielsen report and the selection of the particular core generic skills included in 
university policy. The Nielsen report was concerned with employer satisfaction with graduate skills, many of which related more to the overall qualities expected of conscientious employees, than to the skills acquired by graduates from their study. This emphasis on general rather than discipline-specific graduate qualities was one challenge that had to be considered. Another challenge was to look beyond the current set of desirable skills, and identify future emerging skills and qualities, with a view to incorporating them in policy. Information technology skills and digital literacy is one such example. Even the Nielsen report acknowledged the increasing demand for ICT proficient graduates by a wide range of employers: In regard to course content, we found very few complaints by employers, except in regard to more advanced areas of information technology and electronic communication (ACNielsen, 2000, p. 9). And, commenting on the effect of the IT revolution on the legal services industry, Kift (2003) warned that to ignore it would be to ignore an essential part of undergraduate legal training (p. 12). She went on to say that:

The rapid development of information technology and electronic communication is pervasive and its impacts upon legal practice and professional formation still nascent. Potential developments extend beyond computer based learning and library resources to the wider use of artificial intelligence in the solution or prevention of legal problems. Law schools face the challenge of preparing graduates for a professional career in which such communication modes will be central and unremarkable. (Kift, 2003, p. 12)

The issue of generic graduate skills is not new to tertiary education. The development of such skills in students in the USA for example has been referred to as 'ability-based' education that aimed to develop programs and curricula that would teach students how to handle life's unexpected challenges. There, educators have become involved in the effort to redefine education in terms of abilities needed for effectiveness in the worlds of work, family, and civic community (Mentkowski \& Associates, 2000). These abilities have been defined in terms of learning outcomes and their attributes, and tend to be discipline specific. Moreover, embedded in the general approach is the recognition that attributes should be considered dynamic, and must be constantly reviewed and updated to reflect the changing nature of society and the evolving work environment (Besterfield-Sacre et al., 2000).

The main findings from the Nielsen research report (ACNielsen, 2000) concluded that, overall, the performance of employed new graduates was reasonable, neither particularly high nor low. However, it was the area of skill deficiencies that occupied most of the report. The greatest skill performance shortfalls, given their importance to employers, among new graduates were perceived to relate to creativity and flair, oral business communications, and problem solving. In addition, unsuccessful applicants lacked the capacity for independent and critical thinking, a skill that set them apart from the successful applicants; it was a skill highly valued by employers, but regarded as a rare commodity among applicants. The skill deficiencies most commonly cited by employers were a lack of communication skills, a lack of interpersonal skills, and a lack of understanding of business practice. Graduates from engineering and surveying courses were perceived to be poor in many skills; graduates rated highest overall had either arts/humanities/social sciences qualifications or business/administration/economics qualifications, and these graduates were mostly from the University sector. The survey confirmed that the main reasons given by employers for recruiting graduates, rather than non-graduates, were to enable them to train that person in the organisation's procedures, because they were better educated, to provide tomorrow's managers, and to introduce new ideas or fresh thinking into the organisation (ACNielsen, 2000, pp. vii-ix).

The emphasis of the research, exemplified in the executive summary of the report, was on the recruitment and employment of new graduates in the current business environment wherein 'current' was 1999 - the year when the report data was collected. It is important to see this report in 
perspective since a change in the business environment will undoubtedly lead to a change in the expectations of employers - it is likely to have changed already. The rush to develop generic graduate skills, whether in response to this report or not, is bound to focus solely on traditional skills with a disregard of future skills as a consequence. The changing nature of the means and modes of communication, and of the workplace, caused by the rapid advance of technology, are invariably changing the ways in which generic skills are viewed; these are changes that are only now becoming entrenched in the business environment.

Digital information technologies are rapidly transforming traditional ways of working, learning, and living. It would appear obvious that students need to be prepared for the challenges and possibilities posed by these dynamic technologies. Each defining technology represents an important breakthrough in the ability of humans to communicate with each other; each enables important changes in how we preserve, update and disseminate knowledge; how we retrieve knowledge; the ownership of knowledge; and how we acquire knowledge (Dewar, 1998). Students need to develop new forms of hands-on 'information technology literacy' using new media and a sophisticated understanding of their social impacts, now, in the past, and in the future. Two of the main objectives of 'information technology literacy' would appear to be for students to develop an understanding of the role ICT plays in society, in the past, present, and future; and for students to become literate in new forms of digital communication, including hypertext authoring and the use of graphics, video, sound, and mobile devices.

The development of CGAs is a task that has been embraced by many Australian universities. There are many parallels between the different policies that have been developed, and also differences. What seems to be common among all of them is the apparent absence of 'information technology literacy' as a core graduate attribute. This paper outlines the effort of a particular university to develop a CGA policy, and identifies the challenges that need to be confronted to implement a meaningful and inclusive policy. In particular, the paper highlights the absence of an attribute that should be considered an essential characteristic of a twenty-first century graduate.

\section{The CGA Policy at Victoria University}

The Core Graduate Attributes Policy at Victoria University was developed in response to concerns about improving the employment outcomes of new graduates, and focused on employer satisfaction with graduate skills (ACNielsen, 2000; Sinclair \& Doughney, 2001). The CGAs included problem solving, using information, communication, working as a professional, and appreciating diversity; they aimed to equip graduates with a capacity to lifelong learning. The University has adopted an in-context curriculum integration model for the development of the CGAs with the aim that each attribute should be revisited and assessed both in various subjects, and year by year at progressively higher levels. In addition, as for most students assessment drives learning, the focus should be on assessment tasks (McDowell, 1995).

The details of the policy, that is a set of core graduate attributes, were developed within Victoria University according to the framework provided by Boyer (1990). Boyer defined four complementary aspects of scholarly work: scholarships of discovery (conducting research), integration (making connections within disciplines and across disciplines), application (focusing on professional practice and real-world problems), and teaching (transmission, transformation and extension of knowledge). Candy (2000) maintains that these areas of scholarship are also useful for conceptualising the activities of knowledge workers outside of university. Consequently, the four areas of scholarship coupled with information from employers were used to define the core graduate attributes. These attributes represent generic skills that all students, regardless of area of study, should possess at graduation in addition to the specific knowledge and skills of their disci- 
pline. However, it was recognised, even by Boyer, that the scholarships were interrelated and it was therefore not possible to match each attribute to a single area of scholarship. Nonetheless, it was believed that the four scholarships would provide a useful conceptual framework for the CGA policy. According to the policy, a Victoria University graduate:

1. is an effective problem solver in a range of settings, including professional practice;

2. can locate, evaluate, manage and use information effectively;

3. communicates effectively as a professional and as a citizen;

4. can work both autonomously and collaboratively as a professional;

5. can work effectively in settings of social and cultural diversity.

Each of the above attributes is to be developed at each year level of a course, and relevant criteria for each level have been defined. Since most university undergraduate courses are of three-year duration, a three-level model applies. The students' graduate skills are to be developed progressively over time. Thus they should begin with less demanding and more familiar tasks in the first year of their studies and, in second and third year, proceed with more complex tasks further removed from their original experiences. This process should facilitate students' transition from novice undergraduates to professionals. Although the core graduate attributes have been defined as generic, they are context dependent. Consequently, their integration into the curriculum will vary between disciplines and courses. In fact, the development of graduate skills has been incorporated in most courses across the University for years, albeit in an implicit manner. The CGA policy aims to make this development mandatory, uniform, systemic and explicit. To this end, the implementation process involves course curriculum mapping against the CGAs at course level, and coordination of the overall implementation at faculty level.

Curriculum mapping involves a number of steps to be performed by a course team including a course coordinator, year level coordinators and subject coordinators; firstly, the existing curriculum of each subject needs to be examined to identify learning and assessment activities that support the development of each CGA; secondly, the extent of this support has to be established; thirdly, any gaps and inconsistencies need to be identified and remedied. Curriculum mapping should be applied to as many subjects as possible in a given course but, where the course structure allows a great number of elective subjects, it may be necessary to confine the mapping to core subjects of the course only.

\section{The Absence of ICT Skills in CGA Policy}

Although information literacy is stated as one of the generic attributes of the CGA policy - $a$ Victoria University graduate can locate, evaluate, manage and use information effectively - this attribute does not include any explicit reference to the acquisition and development of ICT skills; such reference was found only in an initial policy document compiled by the CGA Working Group in April 2001 (Victoria University CGA, 2001). The document revealed that the location, management and use of information also includes information technology skills - word processing, spreadsheets, databases including library databases and other discipline specific computer skills. This appears to be the only reference to development of ICT skills in any documents associated with the CGA policy. The attribute itself focuses on information literacy as defined within a library environment, and has been regarded in a similar way by other universities (Council of Australian University Librarians [CAUL], 2001). 
The University adopted a context-specific curriculum integration approach to the development of the CGAs in preference to stand-alone modules specifically designed to develop those attributes. Hence, the development of the CGAs was to be embedded in the discipline knowledge and skills. It was recommended that all curricula involving CGAs make explicit the connections between the attributes developed in the course and requirements for these attributes in the workplace. A Subject Coordinator Kit was developed to assist unit coordinators in mapping of the existing unit curricula against a set of CGA criteria. However, the criteria did not offer any details or examples; they merely spread the general description of each of the CGAs across three year levels. Table 1 shows the three-level criteria describing the information literacy CGA.

Table 1: Three-level criteria for the Information Literacy CGA.

\begin{tabular}{|c|l|}
\hline $\begin{array}{c}\text { Year } \\
\text { Level }\end{array}$ & \multicolumn{1}{c|}{ Criteria } \\
\hline 1 & $\begin{array}{l}\text { Locate credible sources, and locate, evaluate, manage and use basic relevant in- } \\
\text { formation. }\end{array}$ \\
\hline 2 & $\begin{array}{l}\text { Locate, evaluate, manage and use a range of relevant information from a critical } \\
\text { perspective. }\end{array}$ \\
\hline 3 & $\begin{array}{l}\text { Recognise when information is needed, and locate, evaluate, manage and use } \\
\text { information critically for a range of purposes. }\end{array}$ \\
\hline
\end{tabular}

The above criteria make no reference to ICT skills, and provide little elaboration; thus, they are of little practical help to unit coordinators. Even coordinators in a computer science course struggled to detect the implied inclusion of ICT in the information literacy attribute and compiled their unit mappings accordingly. These mappings revealed that development of information literacy apparently was not part of the course. Even the most obvious unit for the initial development of ICT skills, Introduction to Computing and the Internet, did not identify information literacy as a CGA developed in the unit. There were two reasons for this omission: firstly, it is impossible to address a non-existent requirement, i.e. the unidentified ICT skills; secondly, it is difficult to match specific actions and methods used in a unit with generally phrased policy criteria in the absence of sample mappings.

\section{Introducing the ICT CGA}

In today's Information Age, graduates should be able to demonstrate at least the general ICT skills. As the use of new technologies spreads rapidly, ICT skills are already expected of most employees, not only those who choose a career in IT. The general ICT skills could be grouped into two categories:

(1) - the use of software and hardware tools (Windows, word processing, spreadsheet applications, presentation software, database applications, Web applications, mobile applications, mobile devices, hardware and software installation, principles of networks), and

(2) - the responsible use of internet services (e-mail, Web browsing, digital authoring, electronic databases, principles of digital communication).

These two categories of ICT skills should be developed in all graduates regardless of discipline, albeit to varying levels of expertise; the level of expertise will depend on the field of study. 
Given the importance of ICT skills, they should be explicitly incorporated in the CGA policy as a distinct attribute, for example in - a graduate can select and apply appropriate information and communication technology in a skilled and responsible manner. This generic ICT CGA will have to be accompanied by three sets of criteria to facilitate its successful implementation; firstly, a set of generic year-level criteria; secondly, a set of corresponding discipline-specific criteria translated from the generic set; and thirdly, a set of matching unit-specific 'blueprint' for each of the year levels in the discipline. Although the blueprint should ideally include suggestions regarding curriculum design, teaching and learning activities, and assessment, the definition of skills that a student should have developed upon completion of a unit should underpin the subject-specific requirements. An example of a possible specification of the ICT CGA for the field of computer science is depicted in Table 2.

In other disciplines, the specific interpretation of the generic criteria will vary, as will the unitspecific definition of skills. The following tentative suggestions are presented to stimulate discussion - the task of definition is one for experts in the given areas. For example, for Arts students it will be important to develop skills associated with the processing of images and maps; accordingly, they should learn how to use publishing software such as Photoshop, Illustrator and GIS, to manipulate images and maps. Education students should learn ICT skills that will be particularly useful in their profession; this might include extensive proficiency in the use of electronic smartboards. Science students will need to learn how to draw upon text, index, Web, and electronic libraries as information sources and cross-reference information sources. Health sciences students will need to learn how to search for factual information in a variety of databases, use electronic patient records and electronic health records, how to manage health data, information and knowledge, or how to use mobile devices such as PDAs (an important ICT application in many intensive care units). And, music students will have to master the usage of relevant databases (the International Index of Music Periodicals, for example), discographies and catalogues.

The development of a complete specification and the subsequent mapping of unit curricula against the specification is only a prerequisite for the successful realisation of ICT skills as a CGA. An important task, especially with respect to this CGA, will be its regular revision and update to ensure relevance; both the specification and mappings will have to be reviewed. Several other requirements will have to be met, including: a commitment on the part of the University to provide suitable ICT infrastructure; commitment on the part of academic staff to stress the importance of ICT skills and lead by example; willingness of some staff to acknowledge their own ICT skills gaps and their preparedness to undertake training; awareness on the part of the students that the development of ICT skills will enhance their learning experience and improve their professional employment capabilities; and, development of suitable assessment strategies. 
Table 2: Specification of the ICT CGA for Computer Science.

\begin{tabular}{|c|c|c|c|}
\hline & University & CS Course Team & Unit Coordinator \\
\hline $\begin{array}{l}\text { Year } \\
\text { Level }\end{array}$ & Generic Criteria & $\begin{array}{c}\text { Discipline-specific interpre- } \\
\text { tation }\end{array}$ & Unit-specific definition of skills \\
\hline 1 & $\begin{array}{l}\text { Demonstrate ability to } \\
\text { use given information } \\
\text { and communication } \\
\text { technology (ICT) to per- } \\
\text { form prescribed tasks } \\
\text { with guidance. }\end{array}$ & $\begin{array}{l}\text { Competence in using com- } \\
\text { puters, word processing, cal- } \\
\text { culation and graphical soft- } \\
\text { ware, and the Internet. } \\
\text { Awareness of fundamental } \\
\text { ethical questions related to } \\
\text { the access, processing and } \\
\text { dissemination of electronic } \\
\text { information. }\end{array}$ & 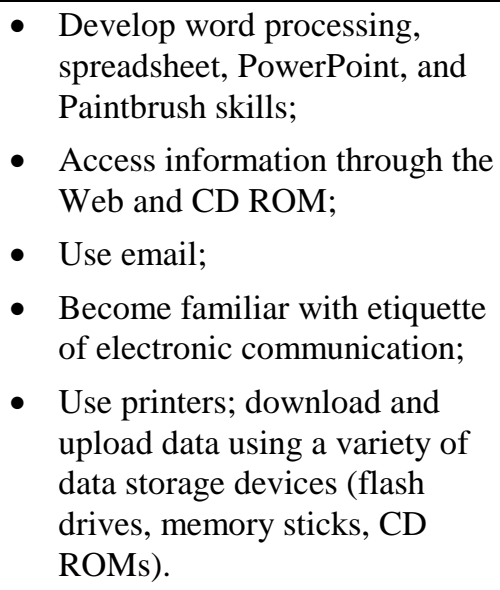 \\
\hline 2 & $\begin{array}{l}\text { Demonstrate ability to } \\
\text { use appropriate ICT to } \\
\text { perform prescribed tasks } \\
\text { with minimum guidance. }\end{array}$ & $\begin{array}{l}\text { Competence in: interfacing } \\
\text { software applications; using } \\
\text { multimedia software and } \\
\text { hardware; using digital com- } \\
\text { munication. } \\
\text { Awareness of rights and re- } \\
\text { sponsibilities in cyberspace, } \\
\text { especially with respect to } \\
\text { privacy, anonymity, disclo- } \\
\text { sure, and intellectual prop- } \\
\text { erty. }\end{array}$ & $\begin{array}{l}\text { - Import and export data across } \\
\text { applications, e.g. between } \\
\text { Word documents and Excel } \\
\text { spreadsheets; Use digital cam- } \\
\text { eras, scanners, microphones } \\
\text { and DVD players; } \\
\text { - Use online discussion groups, } \\
\text { blogs, wikis; } \\
\text { Participate in virtual environ- } \\
\text { ments; } \\
\text { Become familiar with security } \\
\text { mechanisms of software appli- } \\
\text { cations including communica- } \\
\text { tion across the Internet. }\end{array}$ \\
\hline 3 & $\begin{array}{l}\text { Demonstrate ability to } \\
\text { critically select and use } \\
\text { appropriate ICT to per- } \\
\text { form advanced tasks } \\
\text { without guidance. }\end{array}$ & $\begin{array}{l}\text { Competence in: evaluating, } \\
\text { installing and configuring } \\
\text { software. } \\
\text { Proficiency in electronic data } \\
\text { communication. } \\
\text { Awareness of computer secu- } \\
\text { rity and digital etiquette. }\end{array}$ & $\begin{array}{l}\text { - Install and configure software } \\
\text { including firewalls and anti- } \\
\text { virus software; } \\
\text { - Set up simple computer net- } \\
\text { works including modems, mo- } \\
\text { bile devices, and wireless con- } \\
\text { nections; } \\
\text { Develop multimedia applica- } \\
\text { tions including production of } \\
\text { CD ROMs; } \\
\text { - Use electronic communication } \\
\text { in an optimal and sensitive way } \\
\text { (create mailing lists, refrain } \\
\text { from attaching big documents } \\
\text { or sending global emails, etc.). }\end{array}$ \\
\hline
\end{tabular}




\section{Conclusions}

Universities need to be aware of the changing nature of the workplace and the requirements of employers, and must play a role in equipping students with more than a profound knowledge of an academic subject area. They must encourage and enable students to develop, through their academic study, a range of explicit attributes, which will allow them to subsequently engage effectively in the world of work. One of those attributes, particularly in this day and age, is competency in ICT skills.

The development of such skills in students is a challenging task, and appropriate mechanisms have to be put in place to meet the challenge. While addressing the issue at an institutional level is a necessary step, and the introduction of a relevant policy will result in curriculum changes, the success of the policy will depend on effective delivery of the amended curriculum.

However, it is impossible to address a non-existing requirement. If the CGA policy does not include ICT skills as a crucial attribute of any present graduate, then how should its development be addressed? This paper has highlighted this oversight and proposed a way in which it might be addressed in the field of computer science. Further research is needed to develop the blueprint for the ICT CGA in other disciplines.

\section{References}

ACNielsen Research Services. (2000). Employer satisfaction with graduate skills. Research Report 99/7. Retrieved May, 2007 from http://www.dest.gov.au/archive/highered/eippubs/eip99-7/eip99_7pdf.pdf

Besterfield-Sacre, M., Shuman, L. J., Wolfe, H., Atman, C. J., McGourty, J., Miller, R. L., Olds, B. M., \& Rogers, G. M. (2000). Defining the outcomes: A framework for EC-2000. IEEE Transactions on Education, 43(2), 100-111.

B-HERT (2002). Enhancing the learning and employability of graduates: The role of generic skills. Position paper no. 9, Business Education Roundtable, HREF. Retrieved August, 2007 from http://www.bhert.com/publications_PolicyStatements.htm

Boyer, E. L. (1990). Scholarship reconsidered: Priorities of the professoriate. Princeton, NJ: The Carnegie Foundation for the Advancement of Teaching.

Candy, P. C. (2000). Knowledge navigators and lifelong learners: Producing graduates for the information society. Higher Education Research \& Development, 19, 261-277.

Council of Australian University Librarians (CAUL). (2001). Making information literacy legitimate. Retrieved July, 2007 from www.caul.edu.au/surveys/info-literacy2004.doc

Dewar, J. A. (1998). The information age and the printing press: Looking backward to see ahead. RAND Document No: P-8014. Retrieved May, 2007 from http://www.rand.org/publications/P/P8014

Kift, S. (2003). A tale of two sectors: Dynamic curriculum change for a dynamically changing profession. Proceedings of the $13^{\text {th }}$ Commonwealth Law Conferences (pp. 1-13). Retrieved March, 2008 from http://eprints.qut.edu.au/archive/00007468/01/7468.pdf

McDowell, L. (1995). The impact of innovative assessment on student learning. Innovations in Education and Training International, 32(4), 302-313.

Mentkowski, M., \& Associates (2000). Learning that lasts: Integrating learning, development, and performance in college and beyond. San Francisco: Jossey-Bass.

Sinclair, G., \& Doughney, J. (2001). Victoria University's graduate attributes: A brief sample of employer attitudes. Report prepared by the Workplace Studies Centre, Victoria University. 
Victoria University CGA. (2001). Victoria University Core Graduate Attributes Working Group. Retrieved August, 2007 from http://ceds.vu.edu.au/ceds/pdf/cga.pdf

\section{Biography}

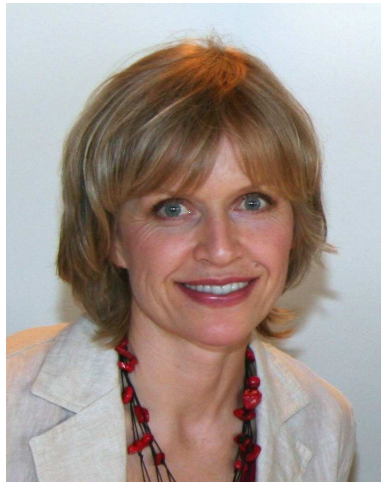

Dr. Iwona Miliszewska is a senior lecturer in computer science at Victoria University, Melbourne, Australia. She has led and participated in research projects involving transnational education, effective teaching methods, lifelong learning and women in computer science, and has published in these areas. 